
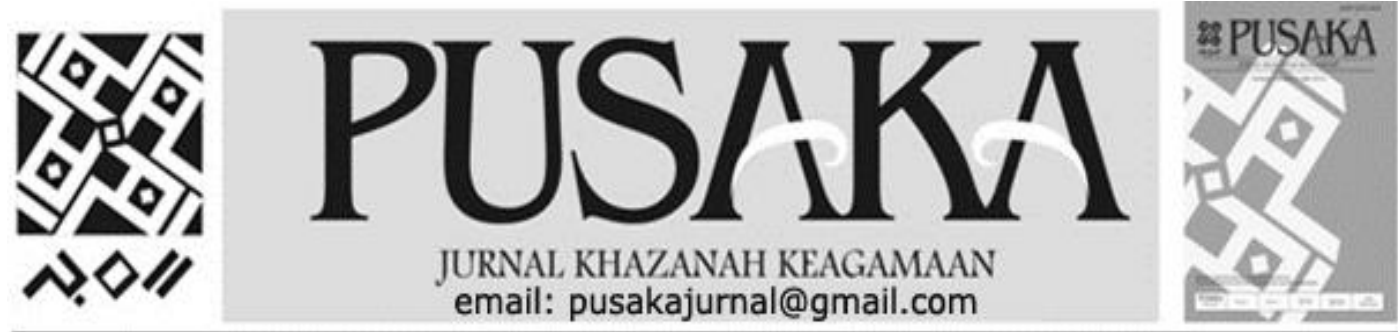

\title{
Kemampuan Baca Kitab Kuning di Pesantren (Studi Komparatif Metode Mumtāz dan Metode Qawaid wa Tarjamah pada Pendidikan Diniyah Formal (PDF)
}

\section{The Ability to read the Kitab Kuning in Islamic Boarding Schools (Comparative Study of the Mumtaz Method and the Qawaid wa Tarjamah Method in Diniyah Formal Education)}

\author{
A. Fajar Awaluddin \\ Institut Agama Islam Negeri Bone \\ Jl. Hos Cokroaminoto Watampone \\ Email:fajarcece82@gmail.com
}

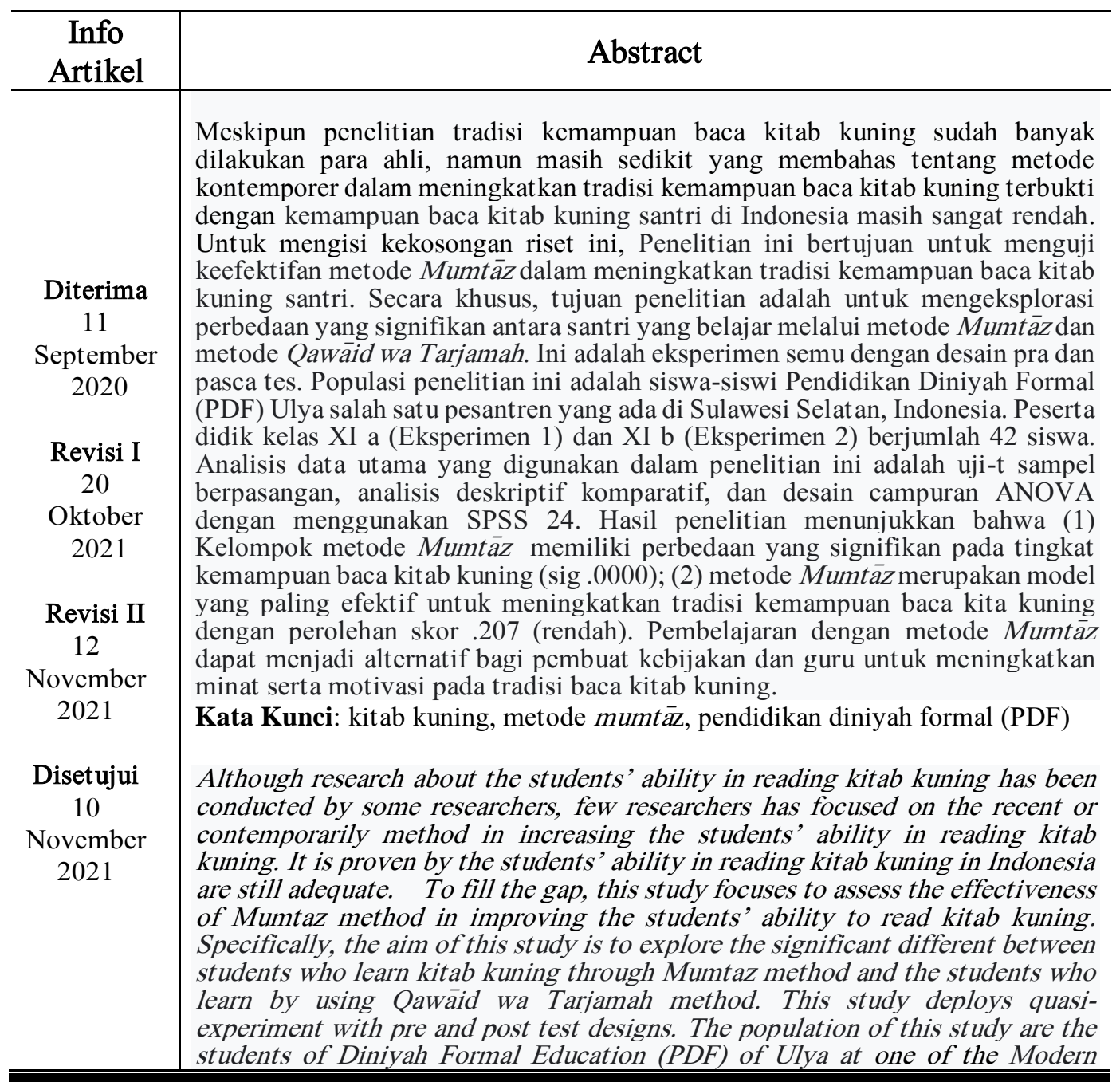


Islamic Boarding School in South Sulawesi, Indonesia. The participants consist of 42 students from two classes; XI a grade (first experiment) and XI b (second experiment). The main data analysis used in this study were paired sample t-test, comparative descriptive analysis, and ANOVA mixed design using SPSS 24. The results showed that (1) the Mumtāz method had a significant difference in the level of students' reading ability in kitab kuning. (sig .0000); (2) the Mumtä method is the most effective model to improve students' ability in reading kitab kuning with a score of .207. Learning using the Mumtäz method can be an alternative for policy makers and teachers to increase students' interest and motivation to read the kitab kuning.

Keywords: mumtāz method, kitab kuning, diniyah formal education (PDF)

\section{PENDAHULUAN}

Predikat kitab kuning pada lembaga pesantren sangatlah strategis dikarenakan kitab kuning telah dijadikan sebagai references, textbook, maupun kurikulum pada sebuah sistem pendidikan pesantren. Selain berposisi sebagai pedoman untuk pola keberaaagaman, kitab kuning pun telah berfungsi sebagai rujukan menyeluruh untuk menyikapi berbagai rintangan kehidupan. Namun demikian, dalam mengkaji makna kitab kuning tersebut terkesan semakin kurang diminati oleh santri disebabkan metode dalam mempelajarinya cenderung membosankan sehingga berefek pada rendahnya kemampuan baca kitab kuning santri di pesantren.

Fakta menunjukkan bahwa problematika Pembelajaran Kitab Kuning di Pondok Pesantren Al-Azhar Bi'ibadillah adalah minimnya guru yang benar-benar kompetensional dan waktu yang terbatas juga dibutuhkan fasilitas pembelajaran yang memadai sehingga pembelajaran tersebut cenderung membosankan (Zailani, 2017). Kendala dalam penerapan pembelajaran kitab kuning dengan metode Talaqqi antara lain : kurangnya minat santri dalam mempelajari kitab kuning, kurangnya waktu belajar, rasa malas, perasaan takut salah ketika membaca kitab di depan ustadz maupun ustadzah, kurang menguasai ilmu Nahwu, Sharof dan bahasa Arab (NUR HALIMAH et al., 2019). Hal tersebut searah dengan pendapat pakar yang menjelaskan pada proses tradisi pengkajian kitab kuning, istilah strategi sudah lazim di gunakan namun digunakan istilah yang berbeda yakni metode ataupun teknik. Metode maupun teknik memiliki definisi yang kurang sepadan walaupun maksudnya memiliki kesamaan. Metode adalah jalan yang harus agar tercapainya sebuah tujuan. adapun teknik adalah cara melakukan sesuatu (Fahrurrozi, 2014).

Sejauh ini, studi tentang metode dan strategi pembelajaran kita kuning cenderung ditinjau dari beberapa perspektif. Pertama, strategi dan metode yang diterapkan dalam pembelajaran oleh pesantren dapat dikategorikan kurang menghasilkan motivasi serta pengawasan kepada santri pada proses pembelajaran kitab kuning selama ini. Akhirnya berdampak pada kurang tertariknya santri untuk hadir dalam proses pembelajaran baik di dalam kelas ataupun keluar dari lingkungan pondok (-Banar et al., 2018). Kedua, kebanyakan santri, terutama santri yang berusia dini serta pemula, mereka merasakan adanya 
kesulitan dalam mempelajari Nahwu serta Sharaf, yang akhirnya memberika efek bagi santri yang berusia dini begitupun pemula tidak bisa aktif dalam pelajaran dengan kecenderungan acuh tak acuh, dikarenakan susah mengerti belajar Nahwu dan Shorrof, padahal fan yang dimaksud adalah kunci untuk mampu membaca kitab kuning (Restu \& Wahyuni, 2019). Dari beberapa kecenderungan di atas tampak bahwa studi yang ada hanya melihat persoalan efek kurangnya minat serta motivasi membaca kitab kuning bagi santri di pondok pesantren, dan juga cenderung hanya menerapkan metode klasik yang terkesan kurang sejalan lagi di era millennial sekarang ini.

Penelitian ini bertujuan untuk melengkapi kekurangan studi terdahulu tentang metode dan strategi dalam menigkatkan kemampuan baca kitab kuning santri di Pesantren. metode Mumtāz salah satu metode yang hadir untuk menjawab tantangan minat dan motivasi membaca kita kuning santri dengan strategi memadukan antara metode klasik dan metode kekinian yang sangat tepat untuk santri millennial di era sekarng ini. metode Mumtāz hadir dalam beberapa tampilan yang memberikan suasana baru dalam proses pembelajaran kitab kuning yakin, Pertama dengan inovasi yang sangat kreatif dalam meracik rumus dan kaidah nahwu saraf dengan perpaduan lagu atau nyanyian yang bersifat komunikatif. Kedua, melakukan terobosan baru dari segi efektifitas waktu dalam pembelajaran kitab kuning yakni dengan metode akselerasi yaitu percepatan mahir membaca dan memahami dalam waktu yang relatif singkat yakni sekitar 2 x 36 jam dengan pengulangan materi $20-40$ kali.
Sejalan dengan itu, ada dua pertanyaan yang dapat dirumuskan, yaitu (1) Bagaimana kemampuan membaca kitab kuning santri pada Pendidikan Diniyah Formal (PDF) Tingkat Ulya dengan menggunakan metode Mumtäa, (2) Apa saja kelebihan dan kekurangan metode Mumtāz dalam menjawab keprihatinan kemampuan baca kitab kuning santri di PDF Ulya?

Penelitian ini didasarkan pada sebuah argumen bahwa metode pembelajaran klasik kitab kuning masih perlu mengalami tampilan yang update seiring berkembangkannya era revolusi industri 4.0. Jika pada umumnya pondok pesantren hanya berdasar pada pembelajaran nahwu saraf klasik tanpa adanya pembaharuan metode, maka akan berefek pada semakin rendahnya minat baca kitab kuning santri. Olehnya itu, penelitian metode Mumtäz ini akan memberikan jawaban bahwa minat santri pada tradisi baca kitab kuning akan mengalami peningkatan seiring berjalannya waktu di era industri ini.

\section{Metode Penelitian}

Penelitian ini merupakan penelitian kuasi eksperimental yang bertujuan untuk mengetahui perbandingan kemampuan baca kitab kuning siswa yang menggunakan metode Mumtāz dan Metode Qawāid wa Tarjamah. Adapun lokasi penelitian pada tulisan ini di Pendidikan Diniyah Formal Tingkat Ulya Al-Junaidiyah Biru Kabupaten Bone. Namun metode Mumtāz ini merupakan metode pembelajaran baru dan belum diterapkan di kelas. Desain penelitian adalah Pre-test dan Post-test Control Group Design. Tujuan penelitian ini adalah untuk mengetahui kemampuan baca kitab kuning siswa antara metode 
Mumtāz sebagai kelompok eksperimen dan Metode Qawāid wa Tarjamah sebagai kelompok kontrol. Kompetensi pertama semua kelompok akan sama dengan uji homogenitas varians dari data pre-test masing-masing kelompok. Oleh karena itu, tujuan penelitian ini adalah mendeskripsikan signifikansi perbedaan antara siswa yang dibelajarkan dengan menggunakan metode Mumtāz dan Metode Qawāid wa Tarjamah dan keefektifan semua metode. Penelitian ini melibatkan 42 siswa kelas XI (usia 15 - 16 tahun) di Pendidikan Diniyah Formal (PDF) Ulya. Kelas pertama hanya diajar dengan Metode Qawāid wa Tarjamah yang terdiri dari total 21 (11 laki-laki dan 10 perempuan) siswa. Kelas kedua berdasarkan metode Mumtāz yang terdiri dari 21 siswa (16 laki-laki dan 17 perempuan). Semua kelas diberikan empat sesi, dan setiap sesi terdiri dari 60-90 menit.

Alat penelitian yang digunakan adalah (1) matriks metode Mumtāz yang berisi kompetensi pembelajaran berdasarkan topik, kegiatan dan penilaian yang diberikan kepada mahasiswa selama masa studi. Telah divalidasi oleh ahli profesional; (2) Garis pedoman untuk Guru yang terdiri dari rencana pelajaran rinci. Hal ini menjadi pedoman bagi guru untuk menyampaikan pembelajaran dengan metode Mumtāz dan Metode Qawāid wa Tarjamah; (3) Materi Pembelajaran berupa modul lain yang dikembangkan oleh peneliti. Setiap modul mencakup beberapa pelajaran untuk siswa, yang menginstruksikan siswa untuk menggunakan perangkat digital untuk mencari informasi secara bebas dan bereksperimen dengan perangkat virtual; (4) Menguji kemampuan baca kitab kuning. Siswa diminta membaca teks Qirāah sesuai aspek tata kaidah dalam pembelajaran kitab kuning. Teks Qirāah juga divalidasi oleh ahli profesional dan uji empiris. Untuk uji empiris diperoleh skala validitas dan reliabilitas. Berdasarkan hasil QUEST semua item dinyatakan valid dengan skala reliabilitas 0,96. Penilaian kemampuan siswa berdasarkan rubrik menggunakan level 0 - 4. Tab/el 1 menunjukkan tingkat keterampilan siswa berdasarkan hasil tes mereka.

Semua siswa diberi satu Qirāah pre-test dan post-test. Hasil tersebut digunakan untuk mengidentifikasi tingkat kemampuan baca kitab kuning siswa setelah mereka dipaparkan pada dua metode yang berbeda. Pertama, kami menyiapkan satu teks Qiraāh berdasarkan aspek tata kaidah pembacaan kitab kuning. Aspek-aspek ini meliputi: a) Menentukan Isim, b) Menentukan Fiil, c) Menentukan Jumlah Ismiyah, d) Menentukan Jumlah Fi'liyah. Dalam studi ini, kami menggunakan SPSS 24 untuk menganalisis data. Profil keterampilan siswa dianalisis dengan statistik deskriptif. Analisis dilakukan dengan menggunakan uji-t berpasangan terhadap hasil tes yang dilakukan oleh siswa untuk mengetahui perbedaan kualitas keterampilan literasi digital mereka. Analisis ANOVA desain campuran digunakan untuk mengetahui perbedaan hasil keterampilan literasi digital pada kelompok metode Mumtāz dan Metode Qawāid wa Tarjamah;. Terakhir, untuk menentukan tingkat efektivitas setiap model, kami menggunakan analisis skor perolehan dengan persamaan Hake (Hake, Wakeland, Bhattacharyya, \& Sirochman, 1994) 
Adapun Uji hipotesis yang digunakan untuk menguji hipotesis penelitian adalah compare means independent sampel $t$-tes dengan menggunakan program Statistical Package for Sosial Science (SPSS) for windows. Pengujian hipotesis dilakukan dengan bantuan program SPSS dengan uji independent sample $T$ test, atau dengan rumus:

Keterangan:

$$
t=\frac{\bar{X}_{1}-\bar{X}_{2}}{\sqrt{\frac{\left(n_{1}-1\right) S_{1}^{2}+\left(n_{2}-1\right) S_{2}^{2}}{n_{1}+n_{2}-2}\left(\frac{1}{n_{1}}+\frac{1}{n_{2}}\right)}}
$$

$$
\begin{aligned}
& \bar{x}_{1} \quad=\text { Rata-rata simpangan } \\
& 1= \\
& \bar{x}_{2} \quad=\text { Rata-rata simpangan } 2 \\
& S_{1}=\text { Simpanan sifatnya } \\
& \text { baku pra perlakuan } \\
& S_{2}=\text { Simpanan sifatnya } \\
& \text { baku pasca perlakuan } \\
& \mathrm{n}_{1} \quad=\text { Jumlah sampel pra } \\
& \text { perlakuan } \\
& \mathrm{n}_{2} \quad=\text { Jumlah sampel pasca } \\
& \text { perlakuan }
\end{aligned}
$$

Adapun hipotesis statistic dalam penelitian ini adalah:

$\mathrm{H}_{0}: \mu_{1}=\mu_{2}$ dan $\mathrm{H}_{1}: \mu_{1} \neq \mu_{2}$,

\section{Kajian Teori \\ Metode dan Kitab Kuning}

Proses pembelajaran kitab kuning baik secara umum maupun secara khusus di pondok pesantren tidak lepas dari peran sebuah metode. Secara bahasa metode diistilah dengan toriqoh yang bermakna jalan. ada beberapa definisi mengenai metode: Pada Kamus Besar Bahasa Indonesia, metode adalah suatu cara melalui proses pemikiran yang baik tujuan dapat meraih maksud dari pengetahuan (Akbar \& Ismail, 2018). Adapun Radliyah Zaenuddin menjelaskan metode merupakan suatu rencana yang bersifat universal dengan kaitannya pada penjelasan materi secara tersusun, yang mana tidak terdapat keterkaitan dengan hal lain dan semua itu didasarkan oleh approach (pendekatan) yang telah ditentukan sebelumnya (Himmah \& Amrulloh, 2018). Menurut Muhibbin Syah Pesantren merupakan tempat belajar agama yang tidak dapat dipisahkan dari pengajaran kitab kuning. Berbagai metode telah dihadirkan untuk digunakan dalam pengajaran kitab kuning. Kitab kuning yang dulunya tidak memerluksn pemahaman tradisi baca kitab kuning dengan penerapan Nahwu dan saraf kini telah dianggap sangatlah sulit untuk dipelajari, olehnya itu beberapa ulama meracik beberapa metode yang gampang didalami oleh peserta didik tanpa harus membutuhkan waktu yang sangat lama dalam mengkaji serta memahami baca kitab kuning (Abdul Wahab, 2016).

Salah satu unsur terpenting dalam mempelajari Kitab Kuning di pesantren adalah kalimat/sintaksnya atau disebut nahwu, qawa'id yang merupakan salah satu ilmu untuk memahami tafsir. Sintaks adalah tata bahasa yang membahas hubungan antar kata dalam ucapan (Verhaar 2006). Menurut Dahdah (1993), sintaksis dalam bahasa Arab identik dengan istilah al-nachw (النحو). Sementara Hermawan (2011) menyatakan bahwa tarakib atau kalimat juga merupakan salah satu permasalahan yang dihadapi masyarakat non-Arab dalam mempelajari bahasa Arab.

Diakui bahwa Pondok Pesantren merupakan lembaga pendidikan tertua dan orisinal yang telah berkarya mencerdaskan kehidupan bangsa dan negara Indonesia. Hingga saat ini tetap 
menjadi lembaga pendidikan yang mendukung dan dibutuhkan oleh masyarakat. Tapi melihat huruf-huruf yang terlihat rumit di buku kuning itu membuat orang ngeri. Keharusan belajar pelajaran nahwu, dengan harakat yang terputar-putar hingga pusing, mesti belajar untuk merefreshkan ketegangan urat, dari sebuah kata perubahannya menjadi banyak kata, begutupun makna yang beragamm pula. Tentu bagi yang masih kesulitan membaca kitab kuning memiliki tafsirnya masing-masing bahkan banyak yang takut bahwa bahasa Arab adalah bahasa tersulit di dunia. (E. Metode \& Lil, 2019).

Pada penelitian sebelumnya, penulis mengambil beberapa sumber sebagai referensi untuk perbandingan. Pertama, Skripsi Uyen Ainifarista dengan penelitiannya yang memberikan penjelasan tentang penerapan pembelajaran nahwu shorof sebagai peningkatan kemampuan dalam membaca kitab kuning. (Restu \& Wahyuni, 2019).

Kedua, Penelitian Azizatul Habibah yang berbicara tentang metode sorogan ayng telah diterapkan untuk mendalami tradisi baca kitab kuning di kelas sharaf Pondok Pesantren AlLuqmaniyyah Yogyakarta, pada hasil tersebut menekankan bahwa metode sorogan tergolong efektif diterapkan unt uk mendidik peserta didik agara bisa aktif, sebab pada metode tersebut peserta didik dihadapi oleh gurunya secara face to face supaya guru/ustadz mampu memahami bagaimana tingkat pemahaman peserta didik oleh berbagai aspek pembelajaran (Widayat, 2017).

Beberapa penelitian ini menganalisis rendahnya resiliensi siswa dalam beradaptasi pembelajaran di pondok pesantren membuat santri minder dan stress dalam berpartisipasi dalam pelajaran termasuk pada tradisi kemampuan baca kitab kuning. Salah satu kelemahan metode kitab kuning adalah kurangnya pemahaman siswa dalam menerjemahkan buku dari bahasa tertentu. Metode pembelajaran kitab kuning menuntut kesabaran, ketekunan, ketaatan dan pribadi dan kedisiplinan siswa agar cepat bosan dalam mempelajari buku. (Ardiansyah, 2020).

Penyebab munculnya masalah pada siswa adalah internal motivasi santri saat memasuki pondok pesantren. Penyesuaian dari budaya santri hingga budaya pesantren, dalam bahasa seharihari, kegiatan di pesantren dan madrasah, tata tertib pesantren dan madrasah dengan etika dimana pesantren itu berada. Metode pengajaran kitab kuning membutuhkan kesiapan santri dalam mempelajari kitab dengan berkonsultasi dengan kyai atau ustadz dan dasar metode pengajaran dalam forum. Metode pembelajaran kitab kuning merupakan salah satu pembelajaran yang memiliki tingkat kesulitan tersendiri dalam pendidikan Islam tradisional karena ini sistem membutuhkan kesabaran, kerajinan, kepatuhan, dan disiplin pribadi siswa (Mulyadi, 2020).

\section{Metode Mumtāz dan Metode Qawāid wa Tarjamah}

Metode Mumtāz merupakan metode yang disederhanakan dengan fokus materi Nahwu maupun Sharaf yang lebih memberikan kemudahan untuk dimengerti. Metode ini juga termasuk salah satu hasil dari inovasi pada metode pembelajaran Bahasa Arab. Proses belajar diterapkan dengan teknik yang memberikan rasa senang 
yang akhirnya tidak memunculkankan rasa bosan pada murid beutupun untuk memberikan keaktifan kepada semua murid untuk memperoleh hasil yang cenderung merata. Disamping diberikan melalui pelatihan, metode ini juga dapat digunakan dalam pembelajaran reguler di madrasah dan pondok pesantren. Sistem yang digunakan pada metode ini adalah sistem buku paket. ${ }^{1}$ Anak yang mampu menguasai materi jilid lebih cepat, Karena sistemnya adalah percepatan maka tidak ada batas waktu minimal dan maksimal, Namun pada umumnya, anak didik menyelesaikan semua materi dalam sepekan (Enam hari). berikut spesifikasi metode Mumtāz:

a. Penyederhanaan materi Nahwudan Sharaf dengan tujuan agar memberikan kemudahan dalam memahami materi tersebut.

b. Proses pembelajaran diterapkan dengan teknik yang memberikan rasa serta suasana senang dengan tujuan tidak memberikan rasa bosan pada siswa serta menjadikan semua siswa lebih aktuf sehingga memberikan hasil yang berimbang.

c. Pengulangan materi $20-40$ kali, selama proses pembelajaran untuk memastikan penguasaan materi sejak di dalam kelas

d. Pelaksanaan secara intensif dan berkesinambungan selama $2 \times 36$ jam

e. Praktek langsung pada teks

f. Evaluasi yang terukur sebelum dan sesudah pelaksanaan penelitian

Sedangkan Metode Qawäid wa tarjamah adalah Seperti namanya,

${ }^{1}$ Alimin, Metode Mumtāz Cara Cepat dan Mudah Pintar Membaca Kitab Kuning, h. v - vi. metode ini letak titik penekanannya pada penguasaan tata bahasa yang digunakan untuk menganalisa sebuah teks. Berdasarkan pandangan tersebut, metode Qawaid Tarjamah memiliki beberapa ciri khas, diantaranya: pertama, Tujuan mempelajari bahasa asing adalah supaya dapat membaca karya sastra asing. Kedua, Materi pelajaran meliputi buku nahwu, kamus, daftar kata, dan teks bacaan. Ketiga, Guru mempunyai peran terpusat selama proses pembelajaran. Keempat, Penggunaan bahasa ibu sebagai bahasa pengantar. Kelima, Basis pembelajaran meliputi proses hafalan teori serta kaidah tata bahasa. Kelima, Kosa kata, kalimat, dan struktur dipaparkan berdasarkan keperluan untuk menjelaskan kaidah nahwu (Jamil \& Sardiyanah, 2020).

\section{HASIL DAN PEMBAHASAN Hasil Analisis Data}

\begin{tabular}{|c|c|c|c|c|}
\hline \multirow{2}{*}{$\begin{array}{c}\text { Ekspe } \\
\text { riment }\end{array}$} & \multicolumn{4}{|c|}{ Nilai Post Test Only } \\
\cline { 2 - 5 } & $\begin{array}{c}\text { Post } \\
\text { Test } \\
\text { I }\end{array}$ & $\begin{array}{c}\text { Post } \\
\text { Test } \\
\text { II }\end{array}$ & $\begin{array}{c}\text { Post } \\
\text { Test } \\
\text { III }\end{array}$ & $\begin{array}{c}\text { Post } \\
\text { Test } \\
\text { IV }\end{array}$ \\
\hline $\begin{array}{c}\text { Qawaid } \\
\text { wa }\end{array}$ & 77. & 83. & 75. & 81. \\
$\begin{array}{c}\text { Tarjamah } \\
\text { (Eksp 1) }\end{array}$ & 8095 & 1905 & 5238 & 9048 \\
\hline $\begin{array}{c}\text { Mumtaz } \\
\text { (Eksp 2) }\end{array}$ & 82. & 71. & 83. & 88. \\
\hline
\end{tabular}

Berdasarkan hasil analisis tabel di atas, dari pemberin tes secara berulang-ulang maka secara keseluruhan dapat diketahui perbedaan kemampuan tes kemampuan dari pemberian perlakuan pada kelas 
ekpsriment 1 dengan menerapkan metode Qawāid wa Tarjamah dan kelas ekpriment 2 dengan menggunakan metode Mumtāz, ternyata menunjukkan hasil bahwa nilai ratarata pada Mumtāz (Ekpriment 2) lebih tinggi dari pada kelas ekspriment 1 yang menggunakan metode Qawāid wa Tarjamah.

\section{Hasil Belajar (Post-Test I) Peserta Didik dengan Menggunakan metode Qawāid wa Tarjamah dan metode Mumtāz dalam meningkatkan kemampuan membaca kitab kuning di PDF Ulya.}

Berdasarkan hasil belajar peserta didik tahapan I pada kelas eksperimen 1 yang belajar menggunakan metode Qawāid wa Tarjamah menunjukkan bahwa nilai tertinggi yang diperoleh peserta didik adalah 95,00, sedangkan nilai terendah 50, dengan rata- rata 77,80, apabila dibandingkan dengan hasil pada kelas ekspriment 2 metode Mumtāz yang menunjukkan nilai tertinggi peserta didik adalah 95,00, dengan rata-rata 82,76. Dengan demikian penggunaan metode metode Qawäid wa Tarjamah dan metode Mumtāz keduanya mampu meningkatkan kemampuan membaca kitab kuning, Walaupun pada pertemuan awal peserta didik masih kelihatan kaku dalam belajar menggunakan metode tersebut.

2. Hasil Belajar (Post-Test II) Peserta Didik dengan Menggunakan metode Qawāid wa Tarjamah dan metode Mumtaz dalam meningkatkan kemampuan membaca kitab kuning di PDF Ulya.

Dari hasil belajar siswa pada tahap I di kelas eksperimen pertama dengan pembelajaran menerapkan metode al-Miftah lil ulum dengan hasil nilai paling tinggi yang didapatkan oleh siswa adalah 95,00, sedangkan nilai terendah 72 , dengan rata- rata 83,19 , apabila dibandingkan dengan hasil pada kelas ekspriment 2 (metode Mumtāz) yang menunjukkan nilai tertinggi peserta didik adalah 90,00, dengan rata-rata 71,47. Dengan demikian penggunaan metode Qawāid wa Tarjamah pada tahapan ini tergolong unggul daripada metode Mumtāz dalam meningkatkan kemampuan membaca kitab kuning pada siswa tersebut. Hal ini ditunjukkan dari peningkatan rata-rata yang signifikan dari tahapan pertama jika dibandingkan pada kelas ekspriment 2 yang menggunakan metode Mumtāz.

Hasil Belajar (Post-Test III) Peserta Didik dengan Menggunakan metode Qawāid wa Tarjamah dan metode Mumtaz dalam meningkatkan kemampuan membaca kitab kuning di PDF Ulya.

Dari hasil belajar siswa pada tahap III di kelas eksperimen pertama dengan pembelajaran menerapkan metode Qawaid wa al-Tarjamah dengan hasil nilai paling tinggi yang didapatkan oleh siswa adalah 90,00, sedangkan nilai terendah 71,47 , dengan rata- rata 83,19 , apabila dibandingkan dengan hasil pada kelas ekspriment 2 (metode Mumtäz) yang menunjukkan nilai tertinggi peserta didik adalah 95,00 , dengan rata-rata 72 . Dengan demikian penggunaan metode Qawāid wa Tarjamah tergolong berada dibawah dalam meningkatkan kemampuan membaca kitab kuning pada siswa tersebut jika dibandingkan pada kelas 
ekspriment 2 yang menggunakan metode Mumtāz.

Hasil Belajar (Post-Test IV) Peserta Didik dengan Menggunakan metode Qawāid wa Tarjamah dan metode Mumtaz dalam meningkatkan kemampuan membaca kitab kuning di PDF Ulya.

Dari hasil belajar siswa pada tahap IV di kelas eksperimen pertama dengan pembelajaran menerapkan metode Qawaid wa al-Tarjamah dengan hasil nilai paling tinggi yang didapatkan oleh siswa adalah 100,00, sedangkan nilai terendah 60 , dengan rata- rata 81,90 , apabila dibandingkan dengan hasil pada kelas ekspriment 2 (metode Mumtāz) yang menunjukkan nilai tertinggi peserta didik adalah 100,00 , dengan rata-rata 88,38 . Dengan demikian penggunaan metode MumtāZ lebih mampu meningkatkan kemampuan membaca kitab kuning pada siswa tersebut. jika dibandingkan pada kelas ekspriment 1 yang menggunakan metode Qawāid wa Tarjamah.

Perbandingan Hasil Belajar Peserta Didik dengan menggunakan metode Qawāid wa Tarjamah dan Mumtāz dalam meningkatkan kemampuan membaca kitab kuning di Pendidikan Diniyah Formal (PDF) Ulya.

Setelah memberikan perlakuan pada kelas ekperimen 1 dan 2 dengan menggunakan metode Qawāid wa Tarjamah dan Mumtāz dalam meningkatkan kemampuan membaca kitab kuning di Pendidikan Diniyah Formal (PDF) Ulya Pondok Pesantren Modern Al-Junaidiyah Biru Kabupaten Bone, hasilnya menunjukkan bahwa metode Mumtaz sangat efektif dalam meningkatkan hasil belajar peserta didik.

Hal ini dapat kita lihat persentase hasil belajar peserta didik kelas yang menggunakan metode Mumtaz (kelas ekperimen 2) dari pada kelas yang menggunakan metode Qawāid wa Tarjamah (kelas ekspriment 1) yang peneliti lakukan memperlihatkan perbedaan hasil belajar peserta didik. Hal ini didukung oleh hasil uji hipotesis yang menunjukan bahwa signifikansi 0,05 yaitu $0,4 \overline{8} 0,05$ yang artinya bahwa, metode mumtaz lebih efiesien untuk meningkatkan hasil belajar siswa.

\section{Kelebihan Penerapan Metode Mumtāz}

Dengan melihat hasil uji statistik antara penerapan metode Qawāid wa Tarjamah dan Mumtāz, maka peneliti menyatakan bahwa metode Mumtāz lebih efektif dalam meningkatkan kompetensi membaca kitab kuning peserta didik pada Pendidikan Pendidikan Formal (PDF) Ulya Al-Junaidiyah Biru Bone. Hal tersebut di buktikan dengan hasil observasi aktivitas pembelajaran dari hasil ujian peserta didik, selain hal tersebut peneliti akan memberikan beberapa alasan keunggulan metode Mumtāz dibanding metode Qawāid wa Tarjamah, sebagai berikut:

1) Teknik Penggunaan kata kunci (Simbol)

Gestalt adalah sebuah teori belajar yang dikemukakan oleh Koffka dan Kohler dari Jerman.Teori ini berpandangan bahwa keseluruhan lebih penting dari bagian-bagian (Arsyad, 2019). Dalam metode Mumtāz, setiap materi dipadukan dengan kata kunci sebagai simbol dalam memahami qaidah nahwu sharaf sehingga dengan kata kunci tersebut memudahkan 
peserta didik mengenali atau mengingat unsur-unsur penting dalam qaidah nahwu saraf yang terkandung dalam materi Mumtāz.

2) Belajar berdasarkan keseluruhan (Satu kesatuan) Ada beberapa prinsip belajar menurut teori Gestalt (Maziyah Ulya UIN Walisongo Semarang, 2017). Belajar berdasarkan keseluruhan Orang berusaha menghubungkan suatu pelajaran dengan pelajaran yang lain sebanyak mungkin. Dalam metode Mumtāz, materi dipaparkan secara menyatu yang berarti bahwa antara materi yang satu dengan materi lainnya secara berkesinambungan terpaparkan dakam dalam satu kesatuan yakni berada dalam satu buku yang terdiri sepuluh pasal (Bab). Ini menandakan bahwa materi yang ada dalam metode Mumtāz terkonsep secara utuh tidak terpisah yang menjadikan mudah dihafal, dicerna atau pahami oleh peserta didik.

3) Metode yang Inovatif

Dalam penerapan metode Mumtāz menciptakan inovasi baru dalam membuat konsep tata qaidah dalam ilmu nahwu saraf yang merupakan dasar utama dalam mempelajari bahasa Arab termasuk dalam membaca kitab kuning. Inovasi yang dimaksud adalah bahwa nadanada yang digunakan dalam lagu (materi) adalah kontemporer yang familiar sehingga mudah dicerna atau dihafal oleh peserta didik. Bukan itu saja, inovasi metode Mumtāz adalah meracik sendiri rumus-rumus yang dipadukan dengan kata kunci yang berbeda dengan metode yang lain yakni membuat lebih ringkas dan lebih simpel dari rumus tata qaidah yang klasik.

\section{Pembahasan}

Rerata kemampuan literasi digital siswa kelompok Metode QawāId $W a$ Tarjamah sebelum proses pembelajaran tergolong rendah (rerata $=0,93, \mathrm{SD}=0,50)$. Dari 10 soal yang diberikan, jawaban siswa yang paling rendah terdapat pada aspek perakitan pengetahuan dengan mean $=0,63$ (rendah). Sedangkan nilai rata-rata jawaban siswa tertinggi adalah variasi isi aspek 1,38 (rendah). Keterampilan literasi digital pada kelompok Metode QawāId Wa Tarjamah berada pada tingkat sangat rendah dan rendah $(34,75 \%)$ sebelum proses pembelajaran. Secara umum berdasarkan hasil pre-test siswa pada kelompok ini memiliki level yang rendah $($ mean $=0,93 ; \mathrm{SD}=0,80)$. Tidak ada siswa yang menunjukkan tingkat yang lebih tinggi. Kualitas keterampilan literasi digital berdasarkan skor post-test berada pada tingkat rata-rata $($ mean $=1,65 ; \mathrm{SD}=$ $0,71)$. Secara khusus, sebagian besar $(65,625 \%)$ siswa menunjukkan tingkat rata-rata keterampilan literasi digital, dan hanya $(9,375 \%)$ pada tingkat tinggi. Perlu diperhatikan bahwa terjadi penurunan jumlah siswa pada tingkat rendah dan sangat rendah serta peningkatan jumlah siswa pada tingkat rata-rata dan tinggi. Secara keseluruhan, Metode QawāId Wa Tarjamah dapat meningkatkan prestasi siswa. Terdapat perbedaan nilai ratarata 0,72 poin (pre dan post test) dan terdapat perbedaan yang signifikan berdasarkan hasil analisis dengan paired sample t-test. Untuk kelompok OLSPBL rata-rata kemampuan literasi digital siswa berada pada level rata-rata (mean $=1,58, \mathrm{SD}=.50)$ pada pre-test. Dari 10 soal yang diberikan, jawaban siswa yang paling rendah berada pada 
aspek menentukan Isim dengan mean $=$ 1,08 (rendah). Sedangkan jawaban siswa tertinggi adalah variasi isi aspek $($ mean $=1,96)$ masih pada taraf ratarata.

Kualitas keterampilan literasi digital yang masih berada pada level rata-rata pada kelompok Metode QawāId Wa Tarjamah menunjukkan bahwa keterampilan mereka berkaitan menetukan Isim. Kualitas keterampilan literasi digital pada kelompok Metode QawāId Wa Tarjamah berada pada tingkat sangat rendah $(21,875 \%)$ dan sedikit $(3,125 \%)$ siswa menunjukkan tingkat rendah dan hanya $(6,25 \%)$ pada tingkat tinggi sebelum proses pembelajaran. Secara umum, siswa dalam kelompok ini memiliki level ratarata $($ mean $=1,58 ; \mathrm{SD}=0,90)$ berdasarkan skor pre-test. Ada dua siswa di tingkat tinggi. Selain itu, kualitas keterampilan literasi digital siswa setelah proses pembelajaran dengan Metode QawāId Wa Tarjamah berada pada taraf rata-rata (mean = $1,81 ; \mathrm{SD}=0,47)$. Secara khusus, sebagian besar $(87,5 \%)$ siswa menunjukkan tingkat keterampilan literasi digital rata-rata, sedikit $(6,25 \%)$ yang menunjukkan tingkat rendah dan hanya $(3,125 \%)$ di tingkat tinggi.

Harus diperhatikan bahwa terjadi penurunan jumlah siswa pada tingkat tinggi dan rendah. Namun, terjadi peningkatan jumlah siswa pada tingkat rata-rata. Namun, tidak ada perbedaan yang signifikan tentang keterampilan literasi digital pada kelompok Metode QawāId Wa Tarjamah. Meskipun terdapat perbedaan nilai rata-rata 0,23 poin (pre dan post test), nilai signifikansi 0,127 0,005. Hal tersebut menunjukkan bahwa pembelajaran Metode QawāId
Wa Tarjamah tidak membantu dalam meningkatkan kemampuan membaca kitab kuning santri. Untuk kelompok Metode Mumtäz, sebelum proses pembelajaran, siswa dalam kelompok ini menunjukkan rendahnya kemampuan literasi digital siswa. Rerata kemampuan literasi digital siswa hanya pada level rendah (rerata $=$ $1,30, \mathrm{SD}=0,06)$. Dari 10 soal yang diberikan, jawaban siswa yang paling rendah terdapat pada aspek perakitan pengetahuan dengan mean $=0,67$ (rendah). Sedangkan jawaban siswa tertinggi adalah aspek pencarian internet $($ mean $=1,64)$ pada taraf ratarata. Sebelum proses pembelajaran, kualitas kemampuan membaca kitab kuning siswa di Kelompok metode Mumtāz berada pada tingkat rendah $(48,48 \%)$ dan sangat rendah $(9,09 \%)$. Hanya sedikit siswa $(42,42)$ yang menunjukkan tingkat rata-rata. Secara umum, siswa dalam kelompok ini memiliki level rendah $($ mean $=1,30$; SD $=0,62$ ) berdasarkan skor pre-test. Tidak ada siswa pada level tinggi. Kualitas kemampuan membaca kitab kuning siswa setelah proses pembelajaran dengan metode Mumtāz berada pada taraf rata-rata $($ mean $=1,98 ; \mathrm{SD}=$ 0,52). Setelah proses pembelajaran, sebagian besar $(84,84 \%)$ siswa menunjukkan tingkat kemampuan baca kitab kuning rata-rata, sedikit $(9,09 \%)$ yang menunjukkan tingkat tinggi dan hanya $(3,03 \%)$ yang menunjukkan tingkat rendah dan sangat rendah. Perlu diperhatikan bahwa terdapat peningkatan jumlah siswa pada tingkat rendah dan rata-rata.

Secara keseluruhan, terjadi penurunan jumlah siswa pada tingkat rata-rata dan tinggi. Ada perbedaan yang signifikan tentang kemampuan 
baca kitab kuning pada kelompok metode Mumtāz. Tabel tersebut menunjukkan bahwa terdapat perbedaan nilai rata-rata 0,69 poin (pre dan post test). Ini menunjukkan bahwa kelompok metode Mumtāz yang digunakan secara signifikan membantu dalam meningkatkan level mereka. Sebagai perbandingan metode pembelajaran dalam penelitian ini, sebagaimana dikemukakan oleh (LaFrance, 2010), bahwa salah satu pembuktian metode pembelajaran dalam meningkatkan kemampuan softskills santri dalam mengkaji kitab kitab kuning. Hal tersebut dapat dibuktikan pada grafik perubahan keterampilan siswa (lihat Gambar 1). Terlihat bahwa siswa pada Metode QawāId Wa Tarjamah memiliki kemampuan awal tertinggi, diikuti oleh kelompok metode Mumtāz. Selain itu, mereka juga diminta membuat peta konsep sesuai dengan informasi yang ditemukan dalam proses pembelajaran.. Saat belajar dengan metode QawāId Wa Tarjamah, mereka tidak diajari keterampilan apa yang harus mereka miliki. Siswa hanya menerapkan pembelajaran sesuai kitab tanpa arahan, berbeda dengan kelas metode MumtāZ yang diajarkan berbagai jenis metode dan model pembelajaran inovatif, komunikatif dan menyenangkan . Berdasarkan temuan penelitian ini, kualitas kemampuan baca kitab kuning sebelum proses pembelajaran sangat rendah untuk semua kelompok. Namun, dalam penelitian ini metode Mumtā merupakan model yang paling efektif untuk meningkatkan kemampuan tersebut. Semua indikator kemampuan baca kitab kuning yang diukur juga mengalami peningkatan. Indikatorindikator ini termasuk menentukan
Isim, Fi'il, Jumlah Ismiyah dan Jumlah Fi'liyah. Ini menunjukkan bahwa metode Mumtāz yang digunakan dalam pengajaran kelompok ini membantu dalam meningkatkan kemampuan baca kitab kuning.

\section{PENUTUP}

\section{Kesimpulan}

Hasil analisis data menunjukkan bahwa pembelajaran metode Mumtāz lebih efektif dalam meningkatkan tradisi kemampuan baca kitab kuning siswa dibandingkan model pembelajaran metode QawāId Wa Tarjamah. Berdasarkan hasil belajar yang dilakukan dalam 4 tahap pengujian (pre-test dan post-test), metode Mumtāz mampu merangsang siswa dalam kemampuan baca kitab kuning dengan menentukan Isim, Fi'il, Jumlah Fi'liyah dan Jumlah Ismiyah. Model pembelajaran metode Mumtāz dapat dikatakan sebagai solusi untuk menyelesaikan permasalahan kemampuan baca kitab kuning siswa. Oleh karena itu, hasil akhir penelitian menunjukkan bahwa terdapat perbedaan yang signifikan (sig .000) antara kelompok metode Mumtäz dan metode QawāId Wa Tarjamah. Selain itu, metode Mumtāz juga terbukti efektif untuk mengajarkan kemampuan baca kitab kuning yang menunjukkan perbedaan yang signifikan (sig .000) antara pretest dan post-test.

\section{Ucapan Terima Kasih}

Artikel ini hadir di hadapan sidang pembaca budiman merupakan sedekah pengetahuan dari berbagai kalangan, terutama para informan yang mengharuskan penulis mengaturkan banyak terima kasih kepada seluruh pihak yang telah membantu 
terlaksananya penelitian ini. Juga kepada Redaktur Pusaka Jurnal Khazanah Keagamaan, atas kesediaannya memuat tulisan ini. Kepada seluruhnya disampaikan Jazakallah Khairan Katsiran.

\section{DAFTAR PUSTAKA}

Abdul Wahab, M. (2016). Standarisasi Kurikulum Pendidikan Bahasa Arab Di Perguruan Tinggi Keagamaan Islam Negeri. Arabiyat: Jurnal Pendidikan Bahasa Arab Dan Kebahasaaraban, 3(1), $32-51$ https://doi.org/10.15408/a.v3i1.31 87

Akbar, A., \& Ismail, H. (2018). Metode Pembelajaran Kitab Kuning Di Pondok Pesantren Daarun Nahdhah Thawalib Bangkinang. Al-Fikra: Jurnal Ilmiah Keislaman, 17(1), 21-32. http://ejournal.uinsuska.ac.id/index.php/alfikra/article/view/5139

Ardiansyah, A. A. (2020). Implementasi Metode Ibridai Dalam Pembelajaran Kitab Kuning Di Pondok Pesantren Hidayaytul Mubtadiien Majalengka. Al-Ittijah - Jurnal Keilmuan Dan Kependidikan Bahasa Arab, 12(1), 1. https://doi.org/10.32678/alittijah.v12i01.1329

Arsyad, M. H. (2019). Metode-Metode Pembelajaran Bahasa Arab Berdasarkan Pendekatan Komunikatif Untuk Meningkatkan Kecakapan Berbahasa. Shaut Al Arabiyyah, 7(1), 13-30. https://doi.org/10.24252/SAA.V1I 1.8269

Banar, E., Pendidikan, J., Pengajaran, D., Maskur, A., \& Anto, P. (2018). Metode Pembelajaran Bahasa
Asing Arab di Pondok Pesantren Modern. El Banar: Jurnal Pendidikan Dan Pengajaran, 1(1), 63-68.

https://staibanisaleh.ac.id/ojs/inde x.php/ElBanar/article/view/10

Fahrurrozi, A. (2014). Pembelajaran Bahasa Arab: Problematika dan Solusinya. Arabiyat: Jurnal Pendidikan Bahasa Arab Dan Kebahasaaraban, 1(2), 161-180. https://doi.org/10.15408/A.V1I2.1 137

Hasin, R., \& Hadi, S. (2019). Strategi Pembentukan Soft Skill Santri Di Pondok Pesantren Mambaul Ulum Putri Bata-Bata Pamekasan. ReJiem (Research Journal of Islamic Education Management), 2(1), 156. https://doi.org/10.19105/rejiem.v2i1.2458

Himmah, R. H., \& Amrulloh, M. A. (2018). Pengembangan Kurikulum Bahasa Arab Pesantren Mu'adalah (Studi Kasus di Pondok Pesantren Al-Kausar Genteng Banyuwangi). Jurnal Al Bayan: Jurnal Jurusan Pendidikan Bahasa Arab, 9(2), 234-248.

https://doi.org/10.24042/albayan.v 9i2.2240

Jamil, H., \& Sardiyanah, S. (2020). Eksistensi Metode Qawaid Tarjamah Dalam Pembelajaran Bahasa Arab Di Era Revolusi 4.0. Jurnal Naskhi: Jurnal Kajian Pendidikan Dan Bahasa Arab, 2(1), 30-39.

https://doi.org/10.47435/NASKHI. V2I1.289

Maziyah Ulya UIN Walisongo Semarang, N. (2017). Pengaruh Metode Pembelajaran dan Tipe Kepribadian Terhadap Hasil Belajar Bahasa Arab (Studi 
Eksperimen Pada MAN 1 Semarang). Nadwa: Jurnal Pendidikan Islam, 10(1), 1-25. https://doi.org/10.21580/NW.2016 .10 .1 .867

Metode, A., \& Ulum, A. L. I. L. (2018). Klasik Di Pondok Pesantren

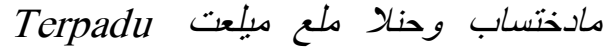

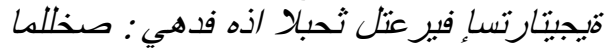

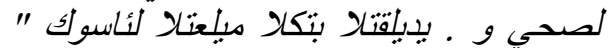

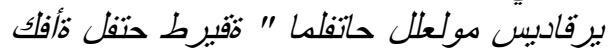

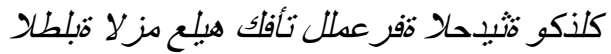

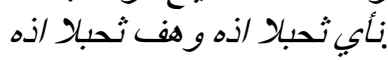

Metode, E., \& Lil, A.-M. (2019). Efektivitas metode al- miftah lil 'ulum dalam meningkatkan kualitas membaca kitab kuning pada santri madrasah diniah. 2(1), 36-48.

Mulyadi, M. (2020). Metode Qawa'id dan Tarjamah dalam Memahami Kitab Kuning. AL-LIQO: Jurnal Pendidikan Islam, 5(01), 25-42. https://doi.org/10.46963/alliqo.v5i 01.143

NUR HALIMAH, M., Us, K. A., \& Munir, M. I. Al. (2019). Penerapan Metode Talaqqi Untuk Meningkatkanketerampilan

Membaca Dan Memahamikitab Kuning Di Pondok PesantrenalBaqiyatush Shalihatkuala Tungkalprovinsi Jambi.

Restu, M., \& Wahyuni, S. (2019). Implementasi Metode Al Miftah Lil Ulum Dalam Membaca Kitab Fathul Qorib Bagi Pemula Di Pondok Pesantren Sidogiri Salafi Kabupaten Pasuruan. Jurnal Intelektual: Jurnal Pendidikan Dan Studi Keislaman, 9(3), 263-272. https://doi.org/10.33367/JI.V9I3.1 025

Sudjani, D. H., \& Gunadi, G. (2020). Thariqah Mubasyarah: Metode
Pembelajaran Bahasa Arab pada Perguruan Tinggi. Tatsqifiy: Jurnal Pendidikan Bahasa Arab, 1(1), 3946.

https://doi.org/10.30997/TJPBA.V $1 \mathrm{I} 1.2573$

Suhaemi, B. (2014). Urgensi Penguasaan Bahasa Arab Bagi Juru Dakwah. Jurnal Ilmu Dakwah.

Thoha, M. (2019). Eksistensi Kitab Kuning Di Perguruan Tinggi Keagamaan Islam (Studi Analisis Tentang Penggunaan Kitab Kuning Sebagai Referensi Kajian Keislaman Di STAIN Pamekasan dan STAI Al-Khairat Pamekasan). NUANSA: Jurnal Penelitian Ilmu Sosial Dan Keagamaan Islam, 16(1), 55. https://doi.org/10.19105/nuansa.v1 6i1.2391

Ummi, H. U., \& Mulyaningsih, I. (2016). Penerapan Teori Konstruktivistik Pada Pembelajaran Bahasa Arab Di Kelompok $28 \quad$ Program Intensifikasi Bahasa Arab Iain Syekh Nurjati Cirebon. Indonesian Language Education and Literature, $1(2), \quad 162$. https://doi.org/10.24235/ileal.v1i2. 600

Widayat, P. A. (2017). Inovasi Kurikulum Bahasa Arab Madrasah Aliyah Berbasis Kontruktivisme. An Nabighoh Jurnal Pendidikan Dan Pembelajaran Bahasa Arab, 19(1),

157. https://doi.org/10.32332/annabighoh.v19i1.762

Zailani, A. (2017). Problematika pembelajaran kitab kuning di Pondok Pesantren Al-Azhar Bi'ibadillah. 